Article

\title{
Who Benefits? How Interest-Convergence Shapes Benefit-Sharing and Indigenous Rights to Sustainable Livelihoods in Russia
}

\author{
Maria S. Tysiachniouk ${ }^{1,2,3, *}$, Laura A. Henry ${ }^{4}\left(\mathbb{D}\right.$, Svetlana A. Tulaeva ${ }^{5}$ and Leah S. Horowitz ${ }^{1,6}$ \\ 1 Nelson Institute for Environmental Studies, University of Wisconsin-Madison, Madison, WI 53706, USA; \\ lhorowitz@wisc.edu \\ 2 The Centre for Independent Social Research, 190041 Saint Petersburg, Russia \\ 3 Environmental Policy Group, Wageningen University, 6706KN Wageningen, The Netherlands \\ 4 Department of Government and Legal Studies, Bowdoin College, Brunswick, ME 04011, USA; \\ lhenry@bowdoin.edu \\ 5 North-West Institute of Management, Faculty of International Relations and Politics, Russian Presidential \\ Academy of National Economy and Public Administration, 197101 Saint Petersburg, Russia; \\ tulaeva-sa@ranepa.ru \\ 6 School of Human Ecology, University of Wisconsin-Madison, Madison, WI 53706, USA \\ * Correspondence: tysiachniouk@wisc.edu
}

Received: 8 October 2020; Accepted: 23 October 2020; Published: 30 October 2020

check for updates

\begin{abstract}
The paper examines interactions of oil companies and reindeer herders in the tundra of the Russian Arctic. We focus on governance arrangements that have an impact on the sustainability of oil production and reindeer herding. We analyze a shift in benefit-sharing arrangements between oil companies and Indigenous Nenets reindeer herders in Nenets Autonomous Okrug (NAO), Russia, as an evolution of the herders' rights, defined as the intertwined co-production of legal processes, ideologies, and power relations. Semi-structured interviews, participant observation, and document analysis demonstrate that in NAO, benefit-sharing shifted from paternalism (dependent on herders' negotiation skills) to company-centered social responsibility (formalized compensation rules). This shift was enabled by the adoption of a formal methodology for calculating income lost due to extractive projects and facilitated by the regional government's efforts to develop reindeer-herding. While laws per se did not change, herders' ability to access compensation and markets increased. This paper shows that even when ideologies of indigeneity are not influential, the use of existing laws and convergence of the government's and Indigenous groups' economic interests may shift legal processes and power relations toward greater rights for Indigenous groups.
\end{abstract}

Keywords: Arctic; benefit-sharing; sustainability; corporate social responsibility; indigenous reindeer herders' rights; triple-helix model: power-law-indigeneity

\section{Introduction}

How, and under what conditions, can formal legal systems, ideologies, and power relations support Indigenous peoples' (IPs') ability to gain some benefit from extractive industry and lead to more sustainable governance of Arctic territories? Focusing on the experiences of the Nenets IPs in the Nenets Autonomous Okrug (NAO), this paper examines how changing dynamics among reindeer herders, oil companies, and state agencies influence financial transfers from oil extraction. Benefit-sharing agreements and compensation for damages to the Nenets IPs have shifted from paternalist principles to company-centered social responsibility (CSSR) [1-3]. Building on Critical Race Theory's insights about the use of law to reinforce inequitable distribution of power and privilege, and TribalCrit's application 
of these insights specifically to IP's lived experiences [4,5], we analyze the changing dynamics in NAO as the evolution of a "triple-helix" of Nenets herders' rights vis-à-vis industry, i.e., the co-production of legal processes, ideologies, and power relations [6]. We demonstrate that, even when ideologies of indigeneity do not explicitly inform governments' decision-making, "interest-convergence" [7] of governments' and Indigenous groups' economic priorities may turn power relations toward greater rights for Indigenous groups, empowering them to pursue sustainable solutions.

In the Russian region of the Nenets Autonomous Okrug, benefit-sharing between Indigenous Nenets reindeer herders and oil companies results from the interaction of formal rules enshrined in Russian law and informal negotiations between companies and the state and between companies and IPs, with the balance of informality and formality changing over time. Before 2010-2011, during the early post-Soviet period, Soviet legacies and weak formal institutions influenced benefit-sharing arrangements between oil companies and IPs; these arrangements were paternalistic, as companies and the state determined the needs of the local populations. The state, largely without community engagement, made decisions about benefits under the categories of financial aid, sponsorship, or companies' 'social responsibility' efforts. However, since 2010-2011, interactions among Indigenous populations, oil companies, and the state started to move away from paternalism toward a stronger role for formal institutions and the rule of law. Indigenous Nenets reindeer herders are better able to use federal laws and the court system and employ new tools to calculate damage to pastures and to achieve more favorable agreements with oil companies.

We characterize this change as a shift from a paternalistic (informal and negotiated) mode to a CCSR mode, which is more formal and rule-bound [3]. CCSR benefits oil companies as it lowers transaction costs and is more predictable; it also appears to result in greater financial resources for IPs. This shift suggests that many private actors prefer formal rules and predictable outcomes, despite this leading to higher payments.

To explain this shift, we draw upon interest-convergence theory [7] to show that a convergence of the economic interests of IPs, companies, and the state can allow IPs to exercise their rights more effectively and gain benefits. Given this convergence, relatively latent laws on indigeneity can gain more practical meaning as implementation strategies change. Even a limited recognition of Indigenous rights, codified in law, can empower actors over time as they gain experience and resources, shifting the power dynamic away from dependence on the state or company. This empowerment can occur even when ideologies valuing indigeneity are not explicitly mobilized, or when they traditionally have been limited to cultural expression. Ultimately, we see modest progress along the triple-helix of Indigenous rights to benefit-sharing when a new approach serves the interests of all actors. However, an authoritarian regime relying on oil and gas exports for revenue, as we see in Russia, does not offer a promising context for the further development of ideologies of indigeneity. It remains an open question whether this shift marks greater recognition of Indigenous rights in the region, or has led to greater empowerment for IPs beyond benefit-sharing.

After introducing the NAO and describing our research methodology, we present the theoretical framework on benefit-sharing regimes and their modes, principles, and mechanisms, and outline the role of law, ideology, and power in the transition from paternalism to CCSR. Next, the article provides background information on the context of NAO by describing benefit-sharing agreements among Indigenous communities and the extractive industry from 1990 to 2019, including the paternalistic mode of interaction and the CCSR mode that has developed since 2012. We then explain the factors contributing to shifts in the levels and types of benefits, including interest-convergence, the use of formal institutions and laws, the changing role of the state, and Indigenous empowerment. We analyze to what extent this shift in modes of benefit-sharing empowers local communities to pursue sustainable solutions. 


\section{Materials and Methods}

We gathered data for this study using qualitative methodologies. Researchers conducted semi-structured interviews, and engaged in participant observation and document analysis. We conducted a total of 95 interviews: 60 interviews with representatives of Indigenous communities and reindeer herding enterprises, 10 interviews with representatives of Indigenous associations (Yasavey, The Reindeer Herding Union, Izvatas), 16 interviews with state authorities, and 9 interviews with managers of oil and gas companies (see Appendix A). Interviews were conducted to elicit information on interactions among IPs, oil companies, and the state authorities. Different interview guides were used for each group of informants. Informants were selected for interviews using a snowball sampling method, which is designed to illuminate the structure of social networks and connect to hard to reach populations [8]. Field work in Russia was carried out in compliance with the Association of Russian Sociologists' guidelines. Oral consent was obtained for all informants. Data sharing with U.S. colleagues was based on a data-sharing agreement between the Centre for Independent Social Research (CISR) in St. Petersburg, Russia and the University of Wisconsin-Madison.

The main interview questions related to the following issues: What legislative opportunities are used by Indigenous people to improve their situation and assert their rights? What conflicts exist between Indigenous people and companies? What is the role of Indigenous non-governmental organizations in addressing existing challenges? What government programs exist to help Indigenous peoples? The duration of each interview ranged from $40 \mathrm{~min}$ to an hour and a half. All interviews were transcribed, and analyzed using thematic and axial coding [8]. The main categories for interview analysis were: formal and informal rules of interaction; causes of conflicts; available resources; strategies for interaction of Indigenous people with other actors. During the analysis, the selected categories were combined into more general theoretical categories: law, power, and indigeneity.

In addition, the following documents were analyzed: federal and regional laws related to the rights of IPs; state programs to support the Indigenous population; corporate reports on sustainable development describing interaction with IPs. Participant observation happened in settlements where the IPs live, including at events such as holidays and training seminars.

The research is part of a longitudinal study that we conducted from 2011 to 2019. Some of the informants gave interviews several times during this period. Repeating interviews allowed us to record and describe the process of social transformation that took place in the region. The sources were triangulated and the information received from informants was correlated with data from documents and observations.

\section{Theoretical Framework}

\subsection{Benefit-Sharing Regimes in the Arctic}

Benefit-sharing involves transferring resources from private actors to communities close to sites of industrial activity. As indicated in multiple international conventions, such as the conventions on international human rights, biodiversity, and the law of the sea, benefit sharing is a legal phenomenon $[9,10]$. Benefit-sharing, which can be considered a regime because of its distinct characteristics, is a system of principles and informal and formal procedures that shape the transfer of resources in a specific area or for a specific project. Every benefit-sharing regime is complex and depends upon international rules and standards, national and regional practices, legacies, power relations, state and Indigenous ideologies, IPs' empowerment, and company practices [3,11].

Previous studies developed a classification of benefit-sharing modes existing in the Arctic, and identified paternalistic, CCSR, partnership, beneficiary, and shareholder modes [12,13]. Each benefit-sharing mode includes a combination of mechanisms, and each mechanism entails a process of transferring resources that depends on what principle is utilized to construct the 
benefit-sharing regime $[3,11]$. This study focused on the paternalistic and CCSR modes, but other arrangements exist in other Arctic regions.

The paternalistic mode is a top-down arrangement of benefit-sharing in which the state or a company plays the central role in determining the level and types of benefits. Often, companies cooperate with the state to fill the gaps in government budgets by delivering support to local communities and IPs. In Russia, negotiations between governments and companies represent a long-standing practice, partly rooted in the history of Soviet state-owned enterprises. Paternalism also was prevalent in the Russian Arctic as a result of the state's inability to provide sufficient services to rural communities after the political upheaval and economic dislocation following the Soviet Union's dissolution $[1,3,14,15]$.

In the CCSR mode, companies prioritize efforts to minimize risks from conflict and reputational damage. In this mode, a company's benefit-sharing agreement adheres to the letter of the law and satisfies stakeholders' basic demands, but requires little effort from the company. In this mode, the benefits are narrowly defined and often take the form of compensation for damages or targeted investments in affected communities. The company retains the leading role in benefit-sharing, and in many ways, makes decisions on benefit-sharing to satisfy its stakeholders and shareholders and comply with legislation. In the CCSR mode, companies usually do not over-comply with laws and rules in use.

Within these modes, benefit-sharing principles define the nature of the benefits. The principle of compensation, which could be reimbursement for damage or loss of lands or profits, suggests that benefits are payments for the effects of extraction. The principle monetizes the damage or lost profits; paying compensation absolves the company of responsibility for the damages. Alternative principles to compensation would be the investment principle (designed to build the capacity of indigenous communities) and the charity principle (in which oil companies voluntarily share revenue with communities) [3].

Benefit sharing mechanisms capture how resources are transferred [13]. National legislation and tax codes, along with contractual obligations, such as royalty payments and production-sharing agreements stipulate streamlined benefits. Negotiated benefits represent ad hoc agreements among companies, regional and municipal authorities, and communities or Indigenous enterprises. Semi-formal benefits occur when a company may choose to provide resources informally by responding to requests from community actors, local authorities, or private citizens. Trickle-down benefits include gains for the communities through general economic impacts, such as employment or new infrastructure development.

Benefit-sharing regimes may change over time. In this paper, we describe a gradual shift from the paternalistic mode to the CCSR mode in the Nenets Autonomous Okrug, and explain why it occurred.

\subsection{Law, Ideology, Power: Triple-Helical Relations}

We analyzed the shift in benefit-sharing arrangements as resulting from a convergence of actors' interests-an alignment which created space for a greater expression of Nenets herders' rights. We define rights as intertwined legal processes, ideologies, and power relations, all three of which co-produce each other [16,17]. We conceptualized this intertwining as a "triple-helix" [6], a model inspired by molecular structures [18]. All three strands (law, ideologies, and power relations) co-evolve in an interdependent way, twisting forward (toward greater rights) or backward (toward diminished rights, i.e., "retrogradation") [19] (see Figure 1). As this case suggests, however, dynamic changes in each strand may not be evenly distributed. Instead, shared interests may lead to greater Indigenous empowerment without a greater acceptance of ideologies of indigeneity. This section outlines ways that legal frameworks, ideologies, and power relations co-evolve, or are subjected to retrogradation. It then introduces the potential of interest-convergence in turning the triple helix. 
$\stackrel{\mathrm{L}}{\mathrm{A}}$

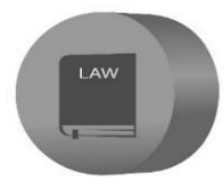

$P$
$O$
$W$
$E$
$R$

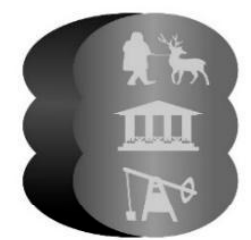

INDIGENOUS PEOPLE STATE

COMPANIES

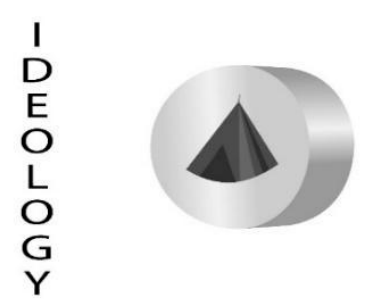

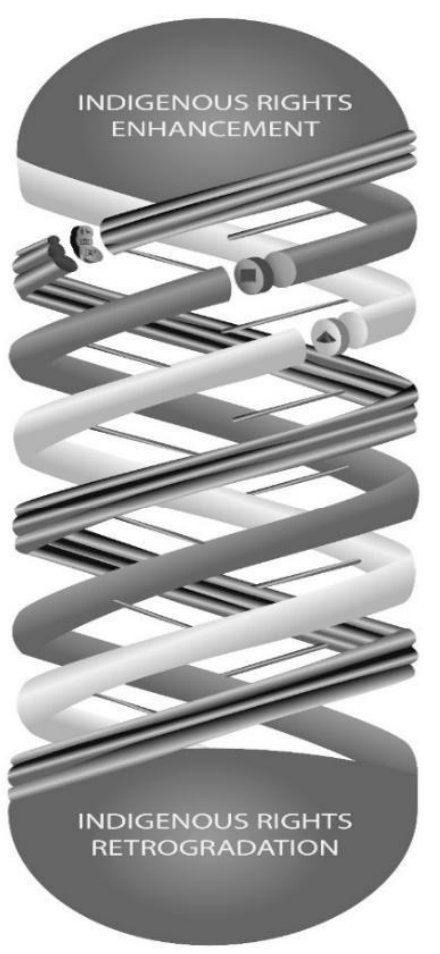

Figure 1. The triple-helix model (designed by Renata A. Tysiachniuk, curated by Alexandra Orlova).

\subsubsection{Laws and Their Limits}

Laws may be hampered by a lack of appropriate implementation and enforcement by those in power-or with power-who do not support the laws' ideological underpinnings [20]. Meanwhile, if a law contradicts social norms [21] or assumed entitlements, then citizens and/or companies will overtly or covertly resist it, reinforcing the conditions that it sought to eliminate.

Nonetheless, legal processes and advocacy can change ideologies [22]. International law, which is generally favorable to IPs' interests and concerns, is notoriously weak because it is largely unenforced, relying on states' voluntary compliance [23]. However, Indigenous leaders' international legal advocacy has shifted discourses about, understandings of, and ideologies surrounding IPs' rights [24]. Ultimately, legal frameworks and decisions shape social norms, moralities, customs and social structures [16,25-27], including benefit-sharing. As social expectations shift, so do power dynamics; ideologies can "embolden" groups and individuals "to view themselves as rights holders" and challenge threats [28].

\subsubsection{Power Relations}

Building upon the understanding that power is not a possession but a relationship, Allen [29] outlines several "modalities" of power. Some punish noncompliance through force (domination) or threats (coercion); others are "quieter" [30], including authority, seduction, manipulation, and inducement. In driving the triple-helix toward greater legal and discursive recognition of Indigenous sovereignty, different individuals and groups are positioned to exercise different power modalities in different ways, places, and moments. Indigenous grassroots groups might not occupy dominant social positions, yet they exercise certain power modalities (e.g., threats of force, and authority based in moral legitimacy) that states or intergovernmental or non-governmental organizations lack [31]. Historically, Indigenous activists' power has been grounded in mobilization of their relationships to particular places [32], like the Nenets' relationship to their land, as we describe below. 


\subsubsection{Ideologies}

Ideologies—shared belief systems, imbued with values, moral commitments, and emotions [33] — can manifest in written or spoken discourses [34] (p. 6), or in non-discursive forms [35] (p. 109). While ideologies are inherently conceptual and cannot be directly observed, they can produce effects-including legal processes and power relations-in ways not explicitly articulated through discourse.

Hegemonic ideologies and their associated discourses can reinforce power relations by justifying dominant groups' legalized oppression of others. Conversely, "counterhegemonic discourses" and ideologies can challenge existing power relations and demand legal reforms [36] (p. 61). For instance, over the last few decades, a new "discursive opportunity structure" [37] (p. 309) has emerged as a radical shift-from descriptions of IPs as 'primitive' or 'savage' to discourses valuing indigeneity, and particularly IPs' relationships to place-has occurred both internationally and in particular localities. Even these discourses are problematic in many ways for IPs [38-42] and scholars have heavily critiqued them [43]. Nonetheless, framing concerns in terms of Indigenous rights now provides globally-recognized political and moral legitimacy, as well as resources through international networks of non-governmental and intergovernmental organizations [44-48].

At the global scale, ideological shifts and Indigenous self-empowerment are reflected in international law. Starting in the 1970s, international agreements emerged to address Indigenous rights, including ILO Convention No. 169 (adopted in 1989) and UNDRIP (adopted in 2007), which recognize, inter alia, IPs' rights to specific territories, environmental protection, and pursuit of development on their own terms [49]. At the domestic scale, local histories and cultures determine the mobilization of relevant international discourses, from "decolonization" and "self-determination" in Canada and the U.S. to "autonomy" and "cultural [ ... ] distinction" in Latin America [27] (p. 47) [50,51]. In the post-Soviet period, global Indigenous political discourses penetrated Russia's political landscape [52]. Concerns about their country's "international image" also influence leaders [53] (p. 37).

\subsubsection{Dynamics of the Triple-Helix}

Turning the triple-helix requires nudges from individual agents-activists, judges, lawmakers, and corporate managers-who, in turn, inevitably emerge from societal power relations and ideological contexts that shape their agency. Decision-makers' agency exists in a dialectical relationship with society-wide ideologies, each shaping the other. As internationally-promoted "human rights norms" become globally accepted, they may be "internalized" as part of local politicians' "belief and identity" [53] (p. 10). Identity-based social movements can also change widespread social norms and convictions, exerting pressure on judges, who tend to respond, albeit reactively rather than proactively [54], with decisions that support those social groups, in turn furthering shifts in power relations $[55,56]$. Hence, ideologies influence actors, who in turn drive change by accessing multiple forms and sources of power, in which ideologies play a part in turn. However, society comprises a multitude of subgroups, which embrace distinct ideologies.

Building upon the triple-helix approach, we argue that the NAO government's support for Nenets reindeer herders' interests is an instance of "interest-convergence" [7]. While Derrick Bell's theory has, to our knowledge, never been applied outside of the U.S. context, we argue that it provides a useful explanatory framework here as well. Bell and others $[57,58]$ have shown repeatedly that, despite superficial appearances of decision-making based in moral enlightenment, the interests of less-powerful groups are only promoted when they coincide with or support powerful elites' interests. Clearly, even though they were a dominant actor, oil companies came to prefer a formal process of benefit-sharing rather than intensive and unpredictable negotiation processes with Indigenous reindeer herders, even if this entailed greater resource transfers; thus, their interest in consistency and predictability converged with the herders' interest in increased compensation and benefits. Meanwhile, the NAO government's interest in promoting reindeer herding as an economic activity coincided with 
Nenets herders' interest in maintaining their livelihoods, which explains the government's willingness to support the herders' claims for greater compensation and benefits from oil companies.

\section{Nenets Autonomous Okrug: Background}

The Nenets Autonomous Okrug is situated in the northwest of Russia (see Figure 2). Most of its territory is above the Arctic Circle. The population is composed of ethnic Russians, Nenets, and Komi. Some Nenets and Komi IPs engage in the traditional livelihood practice of reindeer herding, which, for some, is still their main source of income [59] (p. 51) [60]. In the Soviet period, the regime encouraged Nenets settlement and the creation of collective farms for reindeer and fur and fishing enterprises [61]. Local communities depended on state-owned enterprises and collective farms for social services and community infrastructure. In remote areas, enterprises provided electricity, water, and sewage services, as well as educational and medical facilities, and cultural programs. These Soviet-era practices created persistent expectations about the roles of companies in providing welfare into the post-Soviet period [1].

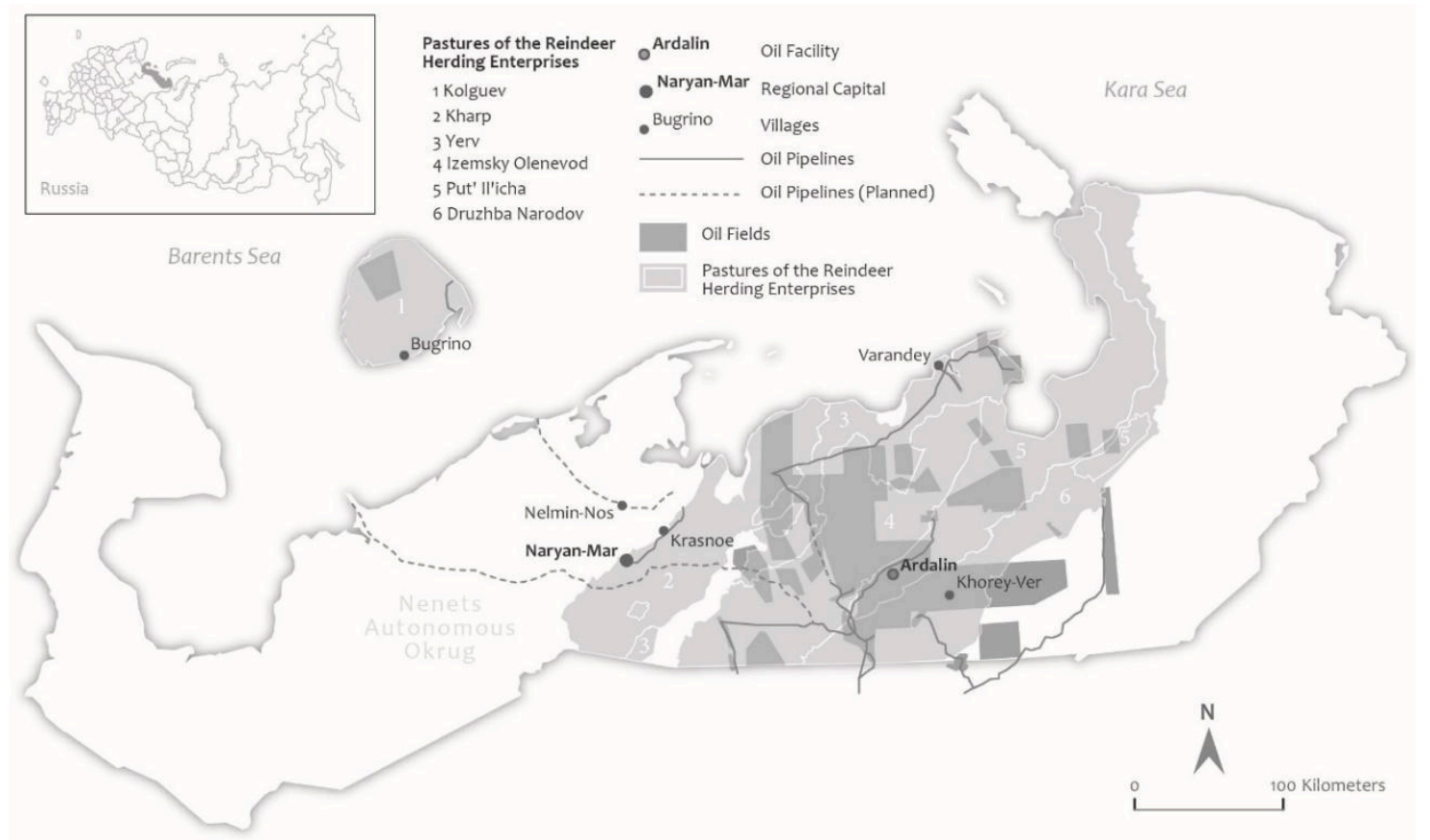

Figure 2. Map of the Nenets Autonomous okrug (designed by Shujin Wang).

The 1991 collapse of the Soviet Union destabilized state support to the Nenets IPs for general community welfare and subsidies to maintain reindeer herds. Following Perestroika and the disintegration of the Soviet regime, collective farms were privatized and restructured, often leaving them to struggle to make a profit. Indigenous reindeer herders have made great efforts to revive reindeer husbandry in the last two decades. At the end of 2019, 23 Indigenous enterprises were active in NAO; 11 were reindeer herders, seven were fishermen, four were Indigenous craft production workshops, and one was a hunting enterprise [62]. Reindeer herders following traditional practices migrate seasonally with their reindeer across the tundra between the NAO and the Komi Republic.

The development of the oil industry in the region also has shaped reindeer herding in NAO [63], leading to the loss of pasture land as well as to environmental degradation in the region [1]. Following the discovery of oil reserves in the NAO in the 1970s, commercial oil production increased in scale in the late 1980s and 1990s. Multinational companies, some of which originated in Russia, dominate the industry in the NAO. Lukoil, working with Vostok NAO, is active in NAO and the neighboring Komi Republic. Other Russian-based companies operate in NAO with foreign partners, such as Total, Statoil, and Petrovietnam. In NAO, oil and gas infrastructure is developing more rapidly than in 
any other region in Russia. In 2017, NAO accounted for 2.86 percent of all oil produced in Russia, which totaled 14.67 million tons of oil [64].

Oil and gas revenues from lease payments for mineral resources' use are the mainstay of the regional budget [65]; $96.5 \%$ of enterprises working in NAO are in the petroleum sector. However, due to Russia's tax code, oil-rich regions still rely heavily on budgetary transfers from the federal government. In NAO, 95 percent of the taxes collected go to the federal budget, with only five percent being returned to the regional budget [66]. NAO also has a production sharing agreement with foreign companies operating in Khariaga, which channels revenue to the region. In addition, property tax and transportation fees from companies are paid at the regional level [67]. Nevertheless, companies are expected to make additional investment in the region where they operate.

\section{Results: From Paternalism to Company Centered Social Responsibility}

\subsection{Paternalistic Mode of Benefit-Sharing (1990-2010)}

From the 1990s to approximately 2010, a paternalistic mode of interaction between oil companies and reindeer herders prevailed in NAO [1]. As noted above, under the paternalistic mode, the state or company (or often both) takes the dominant role in defining and distributing the benefits to IPs. These dominant actors dictate, monitor, and intervene in policies and practices towards communities. This approach may create dependencies on powerful actors, such as the regional government or companies.

In NAO, in the paternalistic mode, companies entered into arrangements with the governor, whereby they allocated some of their profits to social infrastructure in the region. This system was widely acknowledged: "No one can enter the territory without charity support and sponsorship" [68]. In the absence of formal rules to regulate the relationships, negotiations determined the amount of funding channeled to the regions. According to informants, a company's level of oil production was the key factor, but support also was subject to negotiation; the more oil was produced, the higher the government's expectations were for companies. Regional government officials generally proposed the form of support, such as the construction of an ice arena, a school, a sports hall, or a childcare facility in a specific town or a village. An oil company representative explained, "We participate in the okrug development programs, but we do not have a clear program for okrug development as such. They show us that they are planning this and that, so we could have a choice" [69]. In order to operate in the region, companies need to maintain a good relationship with the regional government. In addition to the necessary formal documents and licenses, local authorities provide informal permission in exchange for the company's investment in the social infrastructure of the region.

While the majority of companies' benefit-sharing occurred at the regional level, companies also provided assistance directly to local communities and reindeer herding enterprises; for example, companies have delivered firewood and purchased equipment for schools. Companies generally responded to specific informal requests and considered these benefits to be charity or sponsorship. The head of one community stated, "Agreements between municipal authorities and companies didn't exist. There were human relationships" [70]. Building on the Soviet experience, local residents often expected the companies to solve social and economic problems in their area. An oil company representative commented, "They start switching to questions that are not pertinent to our work. Such as, 'When will we have electricity in our village? Here, you came to build in here, but we don't have electricity.' Or they say, 'When will you build a kindergarten for us?' You see? 'You've come to build your wells, drill the ground, mine oil, and we don't have a kindergarten.'” [69].

During this period, the primary form of benefit-sharing between companies and Indigenous reindeer herding enterprises was a socioeconomic agreement, in which companies provided enterprises with in-kind (or less often financial) support for necessities, usually transport, fuel, and snowmobiles. Companies had separate agreements with each reindeer herding enterprise. The content of those agreements was not made public; often only community leaders knew the exact amount of 
compensation received from a particular oil company. Most of the agreements were short-term. Negotiations determined the level of compensation, which depended on the herders' bargaining skills. If herders lacked knowledge or experience, as many did due to a reliance on custom rather than law or expertise, the compensation sums were small. If community leaders were able to go to court or hire expert organizations to evaluate land use, compensation amounts often were greater.

Both company representatives and Indigenous reindeer herders noted the insecurity and instability of such agreements. A company representative characterized the challenge, stating, "We are building the pipeline, we've already paid for the land, and he says, 'Give me three more tons of diesel fuel.' I say, 'Listen, we already paid you everything.' 'And now give me more, I need it.' I say, 'You're getting brazen.' He goes, 'Well, then I won't let you build."' [69]. Lacking transparency, these agreements between oil companies and reindeer herders depended on situational factors and the outcomes were somewhat unpredictable and subject to revision.

\subsection{Transition from Paternalism to CCSR: Benefit-Sharing Arrangements in 2010-2020}

Around 2010-2012, the paternalistic mode of benefit-sharing began to give way to a new form of interaction that we characterize as CCSR (see Figure 3). A new federal methodology was developed in 2009 and implemented in 2011-2012 to calculate reindeer herders' lost income due to agricultural land taken for industrial development [71]. This methodology provided a platform for more formal relations between oil companies and reindeer herders as compensation was calculated according to a uniform process. In comparison with negotiated agreements, compensation based on the federal methodology is generally more advantageous for reindeer herding enterprises: "The former scheme was less costly for the company ... I mean, the numbers were smaller" [69]. Following the introduction of the new method for calculating damages, reindeer herding enterprises and cooperatives received 35-40 million rubles per year as compensation from oil companies [72]. According to interviews, this compensation constituted a significant part of herding enterprises' annual budgets, often even greater than the profit from reindeer herding. An interviewee estimates, "70 to $80 \%$ is from oil money, plus [state] subsidies" [73].

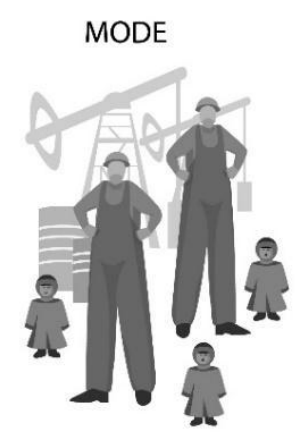

PATERNALISTIC

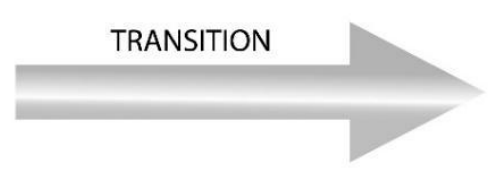

Figure 3. Transition from paternalism to company centered social responsibility (CCSR) (designed by Renata A. Tysiachniuk, curated by Alexandra Orlova).

Although compensation payments were higher than previous funding from socioeconomic agreements, companies agreed to switch to the new methodology because it encouraged transparency and predictability in their interactions with Indigenous groups [72]. The transparent decision-making process significantly decreased the number of disputes. Most of our reindeer herder informants stated that their relationship with the oil companies had stabilized. "There is less conflict with oil companies than with the government. It is easier there. It is people that are doing it." [74]. The methodology also facilitated the resolution of land disputes between oil companies and reindeer herders. For example, when oil companies constructed a new gas pipeline 
through pasture of the Kharp reindeer herders, the enterprise received a one-time payment of 12 million rubles in compensation.

However, earlier paternalist practices also continue. Some reindeer herding enterprises continue to have long-term socioeconomic agreements with companies, and receive funding annually. Companies still occasionally provide small sums to sponsor events. There are other types of agreements between oil companies and reindeer herding communities as well. Easement agreements, which allow companies to use agricultural land, re-categorizing it as industrial land, are signed for the purpose of building winter roads, for example. In addition, reindeer herding enterprises became skilled in soliciting money from other private actors who want to use their lands. For example, Kharp received payment from a paintball company through a temporary easement agreement.

Informal practices persist as well. "Sometimes the oil company people make their own bargain. We give you a car, and you turn a blind eye. These are their relations, we don't interfere." [75]. Reindeer herders note the importance of personal relations that allow problems to be resolved quickly without relying on formal rules. An interviewee describes, "Now they [the company] have appointed a new director-we have to go build a relationship.... When you go to the director, things are done at once." Another states, "Informal relationships with oil companies still exist. They can help with fuel, but with all other issues, you need to negotiate" [72].

Thus, interactions among IPs and oil companies have shifted to a degree. Formal and informal practices co-exist, even as rule-based interactions allow benefit-sharing arrangements with oil companies to become more transparent and stable. Compensation and financial aid from the companies play an important role for reindeer herding communities, especially when state support has fluctuated. "It would be very difficult to survive without the oil industry" [76]. Another interviewee notes, "It is not easy to get by where there is no oil industry. The [state] subsidies have been cut. Our objective is to ensure that the reindeer herders can live normally without the oil industry. Some people, who have the oil industry, are lucky." [77] This process contributes to a shift in power relations as compensation funds are invested in reindeer herding as an agricultural activity, as we explore below.

\subsection{Benefit-Sharing Summary}

We observe both continuity and change in practices of benefit-sharing. The current NAO's benefit-sharing regime incorporates investment (at the regional level), compensation (payments to reindeer herders), and limited charity from companies. Socioeconomic agreements between the state and companies persist and are still broadly negotiated. State agencies continue to use these funds for building infrastructure and social programs to support IPs. Simultaneously, since 2010, the mode of interaction between the IPs and companies has shifted from paternalism to CCSR (see Figure 3).

In the CCSR mode, companies operate in accordance with established rules. Payments based on the methodology calculating lost income are greater than the support that oil companies are provided to IPs in semi-formal social-economic agreements. Therefore, compensation payments have become a partial substitute for sponsorship given by the oil companies to IPs (see Figure 4).

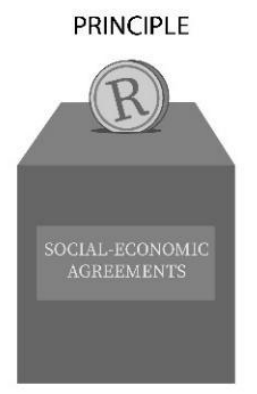

CHARITY

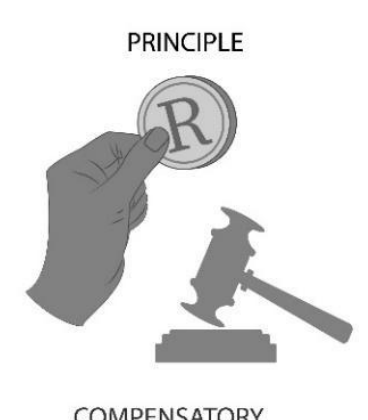

COMPENSATORY

Figure 4. From charity to compensation (designed by Renata A. Tysiachniuk, curated by Alexandra Orlova). 
These regulations and methodologies are more formal, transparent, and predictable than previous semi-formal arrangements and have increased the economic independence of reindeer herders. These formal rules have helped ease tensions between companies and reindeer herders to some degree.

\section{Discussion: Ideology, Law, and Power}

We analyzed this shift in benefit-sharing modes, from Paternalism to CCSR, in terms of the triple-helix model of the co-production of law, power, and ideology (see Figure 5). As we will show, there is a trend toward the gradual empowerment of Indigenous Peoples, based on the revitalization of reindeer herding as a traditional economic activity and the more effective use of existing legislation.

Law, Power, and Ideology Dynamics Over Time

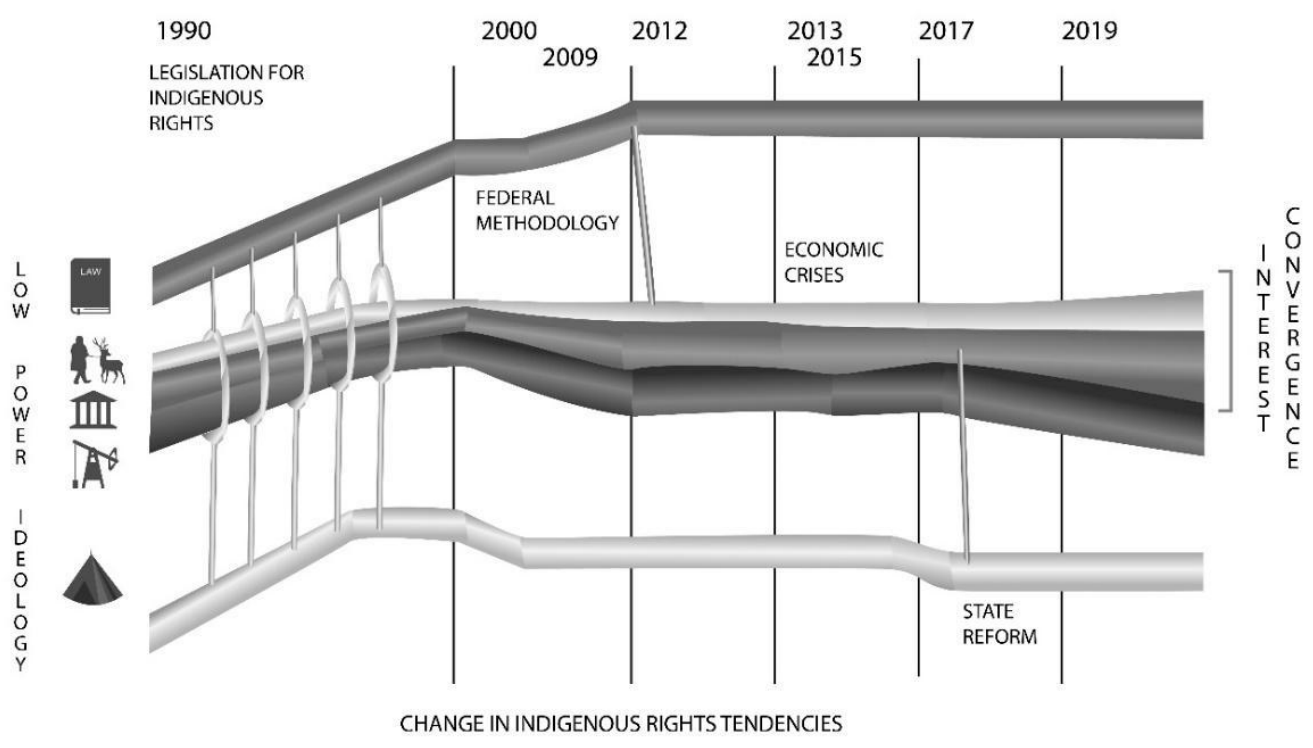

Figure 5. Co-production of law, power, and ideology over time (designed by Renata A. Tysiachniuk, curated by Alexandra Orlova).

We argue that this shift in benefit-sharing was facilitated by convergence of the interests of many actors, which enabled movement away from the status quo to empower Indigenous communities to pursue sustainable solutions. This interest-convergence arose due to deeper shifts in underlying legal processes, ideologies, and power relations, which influence and co-produce each other.

The development of legal norms can contribute indirectly to greater observance of Indigenous rights. While major legislation regarding the rights of Small-Numbered Populations of the North, Siberia and Far East (this refers to IPs) was enacted in the late 1990s to early 2000s, a lack of statutory instruments hampered the practical application of these laws [78]. In 2009, a federal methodology was adopted to calculate compensation for agricultural land easements. This method ensures that there are transparent rules of compensation, decreasing the importance of personal agreements and informal relations and making contracts more secure and stable for both parties. Previously, the amount of compensation was determined in the course of negotiations between oil companies and reindeer herding communities and depended on reindeer herders' skills and experience. The federal methodology led to higher payments from oil companies. At the same time, it also secured the companies against additional requests from reindeer herders. The compensatory payments that reindeer herding communities received from companies were largely spent on physical infrastructure that allowed reindeer herding communities to increase their self-sufficiency. This change in interactions between oil companies and Indigenous communities contributed to the switch of benefit sharing mode from paternalism to CCSR as well as to overall sustainability of reindeer herders' livelihoods. 
Power dynamics shifted as herders' growing self-sufficiency coincided with the reduction of state subsidy payments in 2013-2015. Many reindeer herders noted in our interviews that they can no longer rely on the state and have to rely on themselves. Since 2017, as the economic situation has improved and subsidies are again paid regularly, the regional government also has begun to pay more attention to the voices of reindeer herders. IPs have become more empowered and experienced in using formal laws, rules, and instruments. The herding enterprises learned how to appeal to courts when their rights on pasture uses have been violated. It is noteworthy that the reindeer herders' lawsuits are not only against oil companies, but against other industries and the state as well. Reindeer herders also have started to use scientific expertise for monitoring pasture lands. In addition, they began using modern technologies, such as GIS and helicopter land monitoring of oil spills and land easement borders. A change in the power dynamics and the more active role of Indigenous people was essential in shifting from paternalism to the CCSR model.

\subsection{Ideology: Indigeneity in Russia}

Soviet ideology viewed industrial development as a public good, denying its possible negative effects on the environment or specific population groups. Indigeneity discourses grew in Russia starting in the Perestroika period of the late 1980s when writers and activists helped to define a new approach to Indigenous identities. In 1989, the NAO Nenets Indigenous association, Yasavey, was formed. In 1990, the Association of IPs of the North, Siberia and Far East (RAIPON) was established and in 1993, it was registered as an "all-Russian association" of the Russian Federation. RAIPON has since become a permanent participant to the Arctic Council and has consultative status in the UN Economic and Social Council. It currently collaborates closely with the Russian government. In 2010, the NAO Reindeer Herders' Union, another Indigenous association, was created to develop reindeer herding and preserve it as a traditional economic activity. The Union cooperates with both Russian and international reindeer herding associations, consults reindeer herders on economic issues, and helps herders with official documents.

In the late 1990s and early 2000s, the Russian government passed several important laws in line with global initiatives to protect the rights of IPs to maintain their traditional lifestyles. Russia's 1993 constitution guaranteed IPs rights to land and resources (Article 69). In 1999, the Russia government passed the Federal Law on the Guarantees of the Rights of Indigenous Small-numbered Peoples of the Russian Federation. Other relevant laws include the Federal Law on National Cultural Autonomy (1996), the Federal Law on General Principles of the Organization of Communities of IPs of the North, Siberia, and the Far East (2000), and the Land Code (2001) [78,79]. These laws guarantee IPs' ability to use land for traditional economic activities and receive compensation for damages to their traditional livelihoods. Various subnational governments in Russia's federal system developed regional laws in accordance with these provisions. For example, Indigenous enterprises in NAO received leases to their traditional pastures for 90 years, although similar leases are not available in some other parts of Russia. The flurry of laws passed in the late 1990s and early 2000s, which retrospectively is seen as the peak of Russia's democratization, appear partly to have been the result of Russia's engagement with global institutions and global discourses about indigeneity (see Figure 5).

Indigenous associations played an important role in the implementation of these laws, and indirectly in the shift away from paternalism. In NAO, Yasavey organized a public debate on the implementation of oil and gas projects and compensation for reindeer herders for land seizures [80]. Initially, legal instruments or instructions to establish the amount or manner of compensation did not exist. Yasavey used its access to the regional legislature to suggest laws to enhance the rights of IPs, such as the Law on Reindeer Herding of 2016 [81]. Yasayey also held educational seminars and workshops on IPs' rights, and negotiated on behalf of Indigenous groups with the oil companies. Internationally, experts from Yasavey participated in working groups of the Euro-Arctic Regional Council. Yasavey's own reports document how the organization sought to ensure the rights of IPs in the region, but many of its initiatives were eventually rejected [80]. 
The association managed to increase some subsidies for reindeer herders, but initiatives related to ethnological expertise and traditional nature use were unsuccessful, showing the limits of the association' s influence. Yasavey currently focuses on preservation of traditional culture through state grants and works closely with the Department of the Interior.

Indigenous associations in NAO played a role in the development of legislation related to Indigenous rights. However, over time, the expression of indigeneity in the public sphere largely has been diminished to cultural events. Associations' roles were reduced for several reasons. First, the state began to actively repress NGOs, including Indigenous associations, that had received foreign funding under the 2012 Law on Foreign Agents. The association Yasavey-Manzara, created in 2003 to participate in international partnerships, was listed as a foreign agent and closed. The NAO Reindeer Herders Union has come under state surveillance. According to its leader, "For already three years, the ministry has been on a witch hunt. We cannot be a foreign agent because we don't get foreign money. However, we are still checked, and they still go after us" [75]. Second, government officials have intervened in associations' activities. For example, former state officials replaced the executive directors of Yasavey. Indigenous associations, including Yasavey in NAO, work productively with the regional government. Close cooperation between the regional government and IPs association does help resolve complex issues, but at the cost of greater state control.

The regional government in NAO has divided responsibilities for traditional activities with the Ministry of Internal Affairs overseeing cultural aspects of Indigenous life, while the Ministry of Agriculture administers reindeer herding. However, these changes have not served to embed an ideology of indigeneity further. Space for social activism overall, and for Indigenous activism, has been declining, especially following the Law on Foreign Agents. In NAO, the language of rights is rarely used in discourses related to reindeer herding. However, despite this repression, the state generally supports reindeer herding as a traditional economic activity and as a branch of agriculture.

\subsection{Legislation}

Pro-Indigenous laws passed in the late 1990s and early 2000s today are creating opportunities today for IPs to make claims on industry. Laws guiding relations between IPs, companies, and authorities have contributed to changes in the balance of power relations among actors. As noted above, a number of laws were passed to protect the rights of IPs, but the most consequential for benefit-sharing have been those that shape whether and how IPs control land. In NAO, reindeer herders have acquired formal leases to their pasture land, thanks to the fact that NAO tundra is designated for agriculture. More broadly, the 2001 Land Code restricts the withdrawal of land from agricultural use for industrial activities. This leaseholder status requires oil and gas companies to pay compensation for damages to land that was traditionally used for agriculture activities, such as reindeer herding.

Despite this obligation, for much of the early 2000s, there was no settled process for compensating damages. In 2009, at the federal level, a methodology was adopted to calculate compensation for agricultural land used for industry [71]. In 2011-2012, this methodology came into widespread use in NAO. It allows reindeer herders to determine damages to their profit due to land taken for oil development. Independent agencies calculate the amount of compensation depending on the amount of land used for infrastructure by the oil company and the duration of use. The manner of payment is determined during negotiations between the oil company and the reindeer herding enterprise, resulting in either a one-time payment or installments. Often this compensation is used to construct reindeer slaughtering facilities and meat processing plants, or to purchase new equipment or fuel. As was mentioned earlier, the use of the methodology for calculating profit lost by reindeer herders was a key factor shifting modes of benefit sharing from paternalism to CCSR.

Over time, Indigenous reindeer enterprises have become more likely to appeal to courts to seek redress from companies for oil spill damage. Reindeer herders also have sought to defend themselves against state action. For example, a herding enterprise from Krasnoe filed a lawsuit against an electric company for constructing state-funded power lines on pasture lands. The enterprise 
needed the electricity, but objected to the location [82]. Reindeer herders' greater use of the legal system has somewhat shifted the dynamics between reindeer herders, companies, and the state away from paternalism.

\subsection{Power}

The dynamics of power relations among the oil companies, Indigenous communities, and the state have shifted over time. Interactions between oil companies and reindeer herders in NAO passed through several stages, which caused fluctuations in power dynamics and finally led to the IPs's greater empowerment in negotiation with companies, which consequently decreased their dependence on support from the state.

In the 1970s-1980s, a geological survey for oil had a low impact on nomadic reindeer herders, and the state generously supported reindeer herders. In the 1990s, which was the beginning of intensive oil extraction in NAO, conflict between oil companies and IPs increased. Pipeline construction disrupted reindeer migration across the tundra, and planned reindeer crossing points were often inadequate. In addition, oil extraction affected places that IPs considered sacred. IPs and oil companies also came into conflict over oil spills, which negatively affected rivers, fishing, and pasture quality. These problems led to protests in the 1990s, but over time the power of Indigenous associations has declined.

In 1990-2012, negotiated socio-economic agreements were the primary means of financial support from companies to Indigenous reindeer herders. After 2012, compensation for lost income from land seizure from reindeer pastures to oil infrastructure was formalized. Compensation for damages and lost profits has enabled reindeer herding enterprises to buy necessary equipment and upgrade their facilities, thus strengthening reindeer herding as an economically important agricultural activity. Greater economic sustainability contributes to the decline in paternalistic discourses and makes reindeer herding communities more independent from companies and state authorities. "They're standing on their own feet and they don't need help. They rely on themselves" [83]. A herder agrees, "We are standing on our own feet. The numbers in the herds increased. Enterprises can do reindeer herding independently" [72]. Reindeer herders have started monitoring oil companies using their own helicopter to locate and report oil spills. They also have identified corporate violations of previous agreements about which lands could be taken for industrial development [8]. In this way, Indigenous communities have become less dependent on companies, increasing their ability to live sustainably.

State support for Indigenous reindeer herders also changed over time. During the transition to a market economy in the 1990s, traditional reindeer herding enterprises suffered from low demand for reindeer meat and hides. State support was essential to their survival. Prior to 2013, numerous state programs transferred significant support to reindeer herders from the federal budget and oil companies working in the region. However, funding from state authorities was distributed in a top-down paternalistic fashion. The regional government assisted Indigenous reindeer herders by building housing for herders, sponsoring cultural events, and providing grants for their initiatives (and in some cases even helping with the grant applications). A regional government official recalls, "This was the golden time for the okrug. Schools were built, as were kindergartens and physical training complexes. In this age, money was flowing like a river. [ ... ] However, at that time, resources were distributed ineffectively, which led to carelessness and counting on help" [62].

The regional government also provided subsidies for reindeer herding, which were allocated based on the amount of meat delivered to processing plants. Reindeer herders had to meet certain formal reporting requirements and, in some cases, herding enterprises felt pressured to falsify their reports to meet these requirements. "If you write that you have more reindeer, you can lose subsidies. If you write too little reindeer, again, you can lose subsidies. But you never write the real number, because we are scared to lose subsidies. Once I gave a real number and got in trouble. [... ] You needed to first consult with us so it would be a number that everybody would agree upon, a number that shows you don't have overgrazing" [72]. As the authorities attempted to influence the reindeer husbandry in the region, herders also made their own efforts to navigate a difficult position. 
Relations between reindeer herders and the government changed over time due to declining oil prices that adversely affected the regional budget. State subsidies for IPs, as well as the number and size of government support programs, decreased, particularly during the period of economic crisis from 2013 to 2015, diminishing the ability of the state to exercise a paternalistic approach. State subsidies were often delayed and inconsistent. "Before, the subsidies were 100 rubles per kilogram. Then, the money plunged to 30 rubles. If there is money, they give it. If they don't have it, they don't give it" [75]. This situation caused conflict between reindeer herders and the government: "With the oil companies, there are fewer conflicts than with the state. With companies it is easier" [82]. As reindeer herders were less able to rely on the regional government for assistance, over time they began to expect less help and became more self-reliant, further shifting power dynamics away from paternalism.

In 2017-2018, regional government support of reindeer herding as an agricultural activity again increased. Reindeer herders still needed the subsidies that they are legally entitled to: "You get money from subsidies to buy fuel. It is not necessary to barter with oil companies, but subsidies help to pay" [72]. However, by the time the government resumed regular subsidies, reindeer herders had become more empowered and independent. There are now several new grant programs supporting housing construction and the purchase of equipment [62]. To a large extent, reindeer herders rely on their own resources: “They have a right to subsidies and they get them. [But] they don't really apply to us for available grants. In recent years, there was already economic stability" [84]. State-herder relations have changed in other ways. In May 2018, the NAO Reindeer Herding Council was created to consult on issues related to state support, effectiveness of subsidies, and development of the reindeer herding strategy. Moreover, in 2018, family reindeer herding enterprises, not only large reindeer enterprises, became eligible for subsidies. The NAO government re-established social programs for IPs. After the reorganization of state agencies, several branches of the government became responsible for some aspect of IPs' issues, including the Committee on Nationalities and IPs Policies of the Department of Interior, the Department of Natural Resources, the Department of Education and Culture, the Ethnocultural Center, the Department of Sports, and the Department of Land and Property Regulation. The Committee on Nationalities now hosts seminars on information about legislative developments related to Indigenous issues.

Overall, we see that reindeer herders' interactions with companies are more formal, guided by stable rules, and more transparent. Reindeer herders have increased their independence from the state authorities and appeal to the government officials less frequently than before. They also become less dependent on oil companies, and better positioned to communicate their grievances and use existing rules for greater self-advocacy. Therefore, reindeer herding communities have been able to take steps toward a more sustainable path.

This discussion identifies several long-term trends, revealed by our interviews with IPs, state officials, and oil company representatives and supported by document analysis. These sources demonstrate how the actors' interests converged to result in a shift toward CCSR and somewhat greater empowerment for IPs. Reindeer herders point to their ability to use a new federal methodology to gain compensation for damages to their traditional economic activity and the weakening of their dependency on state subsidies. State officials stress their interest in the economic viability of reindeer herding as an agricultural activity in the region and their desire for peaceful coexistence among IPs and the extractive industry. Oil companies seek less time-intensive and more predictable approaches to benefit sharing with IPs, and to minimize reputational risks. Over time, these interests have resulted in a shift toward a new model of benefit-sharing.

\section{Conclusions}

We observed a clear shift from paternalistic practices in benefit-sharing to CCSR between oil companies and reindeer herders in NAO. Companies in the extractive sector engage with IPs minimally to comply with the law and their own CCSR policies, acquiring a "social license to operate." As part of the shift to CCSR, the mode of benefit-sharing changed from socio-economic agreements framed as charity 
and financial aid to compensation for damages using a formal methodology to calculate lost profits. Meanwhile, a range of mechanisms - streamlined, negotiated, semi-formal, and trickle-down-co-exist, even as a streamlined approach is increasingly dominant.

The adoption of the CCSR approach to benefit-sharing represents the convergence of interests of Indigenous reindeer herders, oil companies, and the regional government. Indigenous herders have interests in greater transparency and increased compensation and benefits. Oil companies prefer the predictability of the formal methodology. Finally, the government benefits from fewer conflicts with the company over benefit-sharing and more reliable funding from the companies to the herders, which supports local reindeer herding enterprises, an economic activity the government wants to encourage. We see this interest-convergence as the result of several long-term trends revealed by our interviews and document analysis. These trends are rooted in deeper shifts in underlying legal processes, and power relations, despite the lack of change in ideological discourses. Specifically, we see, first, the development a statutory instrument to make earlier laws more meaningful in practice through the development of a federal methodology to calculate compensation for damages from extraction that allows IPs to better defend their own rights and, second, a shift in the relations between the state and IPs, as a temporary decline in subsidies for reindeer herding requires new strategies of self-reliance among IPs.

While interest-convergence has resulted in improved conditions for Nenets herders, we remain cautious about overall implications for Indigenous rights. Although we see the shift from more paternalistic and informal models of benefit-sharing to more CCSR-oriented and formal approaches to compensation for damages, ideologies of indigeneity remain weakly institutionalized in NAO. Recent changes in implementation of earlier laws on Indigenous rights have extended some power to IPs in their interactions with companies, but the current authoritarian political context in Russia more generally appears unfavorable for extending Indigenous rights further. However, the growing market power of Indigenous actors provides a glimmer of hope.

Ideologies of indigeneity have not become firmly rooted in Russia, despite the creation of relevant institutions and laws. Indigenous mobilization, prevalent in the Perestroika period, declined during the post-Soviet period's severe economic recession. Indigenous activists from Russia who are able to attend forums at the international level employ rights language, but this has not trickled down to NAO, where oil companies and IPs have focused on developing strategies for sustainable coexistence. The state has made some efforts to encourage reindeer herding as an economic activity, but seemingly not due to its ties to indigeneity. NAO may be exceptional, as reindeer herders have been able to lease their traditional pastures. At the same time, the codification of Indigenous rights in major pieces of legislation in Russia was a critical juncture for IPs. These laws continue to provide opportunities for IPs to demand compensation and this case demonstrates how they can be implemented more fully over time.

Legally, we see the belated introduction of an approved methodology for calculating compensation for damages to traditional Indigenous economic activities. This rather modest regulatory change has allowed for the more complete implementation of laws passed in the late 1990s and early 2000s. However, this methodology does not recognize any non-economic impacts on IPs; as IPs have become more experienced, they also have been able to take advantage of the courts to achieve compensation, in some cases. At the same time, Indigenous activism is repressed through the use of the foreign agent law or state surveillance.

Changes in the balance of power are also limited. The methodology for calculating damages only works for IPs who have a lease to their agricultural land, which is the case in NAO, but not in all regions of Russia. In NAO, companies seized upon the methodology as a more predictable option than negotiations; IPs embraced the methodology as it generally offered greater compensation, even as they continue to negotiate informally in some instances. This shift mitigated the power imbalances between companies and IPs to some degree. The methodology also came into use during a period when the regional government was less able to pay subsidies to reindeer herders due to financial challenges. 
In addition, regional government agencies have become stronger advocates of Indigenous reindeer herders as part of the region's agricultural economy. Reindeer herders also have invested in processing plants and other infrastructure to allow more robust participation in the market economy, diversifying the flow of resources, and making themselves less reliant on other actors. Ultimately, our findings supported the interest-convergence thesis by demonstrating that Nenets herders' improved conditions are delimited by the boundaries of the overlap of their interests with those of oil companies and the regional government.

In NAO, we observed a relatively stable situation in which companies practice CCSR and coexist with the reindeer herders with minimal conflict as companies acknowledge Indigenous reindeer herders' right to compensation. This begs the question: Is this a path to economic and social sustainability? Future research will be important to identify the mechanisms for benefit co-management [3] that would share oil rent in a fair and equitable way, going beyond compensation, and also would address environmental concerns.

Author Contributions: Conceptualization, M.S.T., L.A.H. and L.S.H.; methodology, S.A.T. and M.S.T;; validation, M.S.T. and S.A.T.; formal analysis, M.S.T. and L.A.H.; investigation, M.S.T., L.A.H. and S.A.T.; resources, M.S.T.; data curation, S.A.T.; writing - original draft preparation, M.S.T. and S.A.T.; writing — review and editing, L.A.H. and L.S.H.; visualization, M.S.T.; funding acquisition, M.S.T. All authors have read and agreed to the published version of the manuscript.

Funding: This work has been partially supported by the Netherlands Organization for Scientific Research (NWO) Arctic Program ("Developing benefit sharing standards in the Arctic", No. 866.15.203), the Finnish Academy Arctic Program ("Oil Production Networks in the Russian Arctic", No. 286791), the Fulbright Arctic Initiative, and the University of Wisconsin-Madison.

Acknowledgments: We are thankful to Renata Tysiachniouk and Alexandra Orlova for illustrating this article and designing the visual abstract, Lena Richter for providing valuable assistance with editing this manuscript, and to Shujin Wang for making the map.

Conflicts of Interest: The authors declare no conflict of interest.

\section{Appendix A}

Table A1. List of informants.

\begin{tabular}{|c|c|c|}
\hline Date & Location & Person \\
\hline \multicolumn{3}{|r|}{ NAO } \\
\hline 28 May 2011 & Naryan-Mar & Deputy director of a reindeer enterprise \\
\hline 28 May 2011 & Naryan-Mar & Vice-president, member and Duma Deputy of Polar district \\
\hline 29 May 2011 & Naryan-Mar & Representatives of Lukoil-Komi company \\
\hline 1 June 2011 & Naryan-Mar & Researchers at the reindeer husbandry experimental station \\
\hline 1 June 2011 & Naryan-Mar & Deputy director of the Department of Natural Resources \\
\hline 1 June 2011 & Naryan-Mar & Adviser to the NAO Governor \\
\hline 1 June 2011 & Naryan-Mar & $\begin{array}{c}\text { Director of the Agency on Indigenous People and Traditional } \\
\text { Nature Use }\end{array}$ \\
\hline 2 June 2011 & Naryan-Mar & Representative of the regional movement Izviatas \\
\hline 2 June 2011 & Naryan-Mar & $\begin{array}{c}\text { Indigenous Nenets people, living in Naryan-Mar previously } \\
\text { involved in reindeer herding-1 }\end{array}$ \\
\hline 2 June 2011 & Naryan-Mar & $\begin{array}{c}\text { Indigenous Nenets people, living in Naryan-Mar previously } \\
\text { involved in reindeer herding - } 2\end{array}$ \\
\hline 3 June 2011 & Naryan-Mar & $\begin{array}{c}\text { Indigenous Nenets people, living in Naryan-Mar previously } \\
\text { involved in reindeer herding-3 }\end{array}$ \\
\hline 4 June 2011 & Village A & Director of the boarding school \\
\hline 4 June 2011 & Village A & School director \\
\hline 4 June 2011 & Village A & Housing employee \\
\hline 4 June 2011 & Village A & Retired person \\
\hline 4 June 2011 & Village A & Director of municipality \\
\hline 4 June 2011 & Village A & Director of the People's Deputy Council \\
\hline 4 June 2011 & Village A & People's Deputy member \\
\hline
\end{tabular}


Table A1. Cont.

\begin{tabular}{|c|c|c|}
\hline Date & Location & Person \\
\hline \multicolumn{3}{|r|}{ NAO } \\
\hline 5 June 2011 & Village A & $\begin{array}{c}\text { Polar Lights company representatives: Director of oil and } \\
\text { gas development }\end{array}$ \\
\hline 5 June 2011 & Village A & $\begin{array}{c}\text { Polar Lights company representatives: Deputy director of oil } \\
\text { and gas development }\end{array}$ \\
\hline 5 June 2011 & Village A & Representatives of reindeer herder cooperative- -1 \\
\hline 5 June 2011 & Village A & Representatives of reindeer herder cooperative- -2 \\
\hline 5 June 2011 & Village A & Representatives of reindeer herder cooperative- -3 \\
\hline 6 June 2011 & Village B & Director of the kindergarten \\
\hline 6 June 2011 & Village B & Director of sport centre \\
\hline 6 June 2011 & Village B & Director of the folk group \\
\hline 6 June 2011 & Village B & Director of ethno-cultural centre \\
\hline 6 June 2011 & Village B & School director \\
\hline 6 June 2011 & Village B & Teacher of geography \\
\hline 7 June 2011 & Village B & Director of municipality \\
\hline 7 June 2011 & Village B & Director of the People's Deputy Council \\
\hline 7 June 2011 & Village B & Director of the housing commission \\
\hline 7 June 2011 & Village B & People's Deputy member-1 \\
\hline 7 June 2011 & Village B & People's Deputy member-2 \\
\hline 8 June 2011 & Village B & Director of the brigade \\
\hline 8 June 2011 & Village B & Reindeer herder-1 \\
\hline 8 June 2011 & Village B & Reindeer herder-2 \\
\hline 8 June 2011 & Village B & Reindeer herder -3 \\
\hline 8 June 2011 & Village B & Reindeer herder -4 \\
\hline 9 June 2011 & Village C & Cultural worker \\
\hline 9 June 2011 & Village C & Director of folk group \\
\hline 9 June 2011 & Village C & Director of veteran's council \\
\hline 9 June 2011 & Village C & Folk group singer \\
\hline 9 June 2011 & Village C & Hunter \\
\hline 10 June 2011 & Village C & Local newspaper editor \\
\hline 10 June 2011 & Village C & Retired person-1 \\
\hline 10 June 2011 & Village C & Retired person-2 \\
\hline 10 June 2011 & Village C & Teachers of Nenets language and culture \\
\hline 10 June 2011 & Village C & Director of the municipality \\
\hline 10 June 2011 & Village C & Director of the People's Deputy Council \\
\hline 10 June 2011 & Village C & People's Deputy member \\
\hline 11 June 2011 & Village C & Director of the brigade \\
\hline 11 June 2011 & Village C & Dispatcher at the reindeer cooperative \\
\hline 11 June 2011 & Village C & Reindeer herder-1 \\
\hline 11 June 2011 & Village C & Reindeer herder-2 \\
\hline 11 June 2011 & Village C & Reindeer herder-3 \\
\hline 11 June 2011 & Village C & Representative of reindeer cooperative \\
\hline 13 June 2011 & Naryan-Mar & Representative of the oil company-1 \\
\hline 13 June 2011 & Naryan-Mar & Representative of the oil company-2 \\
\hline 14 June 2011 & Naryan-Mar & Representative of the oil company-3 \\
\hline 14 June 2011 & Naryan-Mar & Yasavei executive director and lawyers \\
\hline 14 June 2011 & Naryan-Mar & Yasavei lawyer \\
\hline \multicolumn{3}{|r|}{ Moscow } \\
\hline 16 April 2015 & Moscow & Representative of the oil company \\
\hline \multicolumn{3}{|r|}{ Komi } \\
\hline 10 February 2015 & Usinsk & Representative of the oil company-1 \\
\hline \multicolumn{3}{|r|}{ NAO-2017 } \\
\hline 10 January 2017 & Naryan-Mar & Representatives of reindeer herder cooperative- -1 \\
\hline 10 January 2017 & Naryan-Mar & Researcher \\
\hline 11 January 2017 & Naryan-Mar & Director of reindeer herder cooperative- -1 \\
\hline 12 January 2017 & Naryan-Mar & Representative of NGO Yiasavey \\
\hline 11 January 2017 & Naryan-Mar & Representatives of reindeer herder cooperative- -2 \\
\hline 11 January 2017 & Naryan-Mar & Representative of NAO reindeer herder Union \\
\hline 11 January 2017 & Naryan-Mar & Representatives of reindeer herder cooperative- -3 \\
\hline
\end{tabular}


Table A1. Cont.

\begin{tabular}{|c|c|c|}
\hline Date & Location & Person \\
\hline \multicolumn{3}{|r|}{ NAO-2017 } \\
\hline 12 January 2017 & Naryan-Mar & Department of Indigenous People \\
\hline 12 January 2017 & Naryan-Mar & Department of Regional Politics \\
\hline 13 January 2017 & Village C & Director of reindeer herder's enterprise -1 \\
\hline 14 January 2017 & Village C & Representatives of reindeer herder's enterprise- -4 \\
\hline 14 January 2017 & Village C & Representative of local administration-1 \\
\hline 14 January 2017 & Village C & Representative of local administration -2 \\
\hline \multicolumn{3}{|r|}{ NAO-2019 } \\
\hline 20 December 2019 & Village A & Director of the reindeer herder enterprise \\
\hline 22 December 2019 & Village C & Director of the reindeer herder enterprise \\
\hline 22 December 2019 & Village C & Representative of the reindeer herder enterprise- -1 \\
\hline 23 December 2019 & Village C & Representative of the reindeer herder enterprise -2 \\
\hline 23 December 2019 & Village C & Representative of the reindeer herder enterprise- -3 \\
\hline 23 December 2019 & Village C & School teacher-1 \\
\hline 23 December 2019 & Village C & School teacher-2 \\
\hline 24 December 2019 & Naryan-Mar & Representative of the reindeer herder enterprise- -1 \\
\hline 24 December 2019 & Naryan-Mar & Representative of the cultural centre \\
\hline 24 December 2019 & Naryan-Mar & Representative of the reindeer herder enterprise -2 \\
\hline 25 December 2019 & Naryan-Mar & Director of the reindeer herder enterprise -1 \\
\hline 25 December 2019 & Naryan-Mar & Representative of the reindeer herder union \\
\hline 25 December 2019 & Naryan-Mar & Representative of Indigenous Association \\
\hline 25 December 2019 & Naryan-Mar & Director of the reindeer herder enterprise -2 \\
\hline 25 December 2019 & Naryan-Mar & Representative of the state authorities of the okrug-1 \\
\hline 26 December 2019 & Naryan-Mar & Representative of the state authorities of the okrug-2 \\
\hline 27 December 2019 & Naryan-Mar & Former representative of the reindeer-herder enterprise \\
\hline
\end{tabular}

\section{References}

1. Henry, L.A.; Nysten-Haarala, S.; Tulaeva, S.; Tysiachniouk, M. Corporate Social Responsibility and the Oil Industry in the Russian Arctic: Global Norms and Neo-Paternalism. Eur. Asia Stud. 2016, 68, 1340-1368. [CrossRef]

2. Tysiachniouk, M.S.; Petrov, A.N.; Kuklina, V.; Krasnoshtanova, N. Between Soviet Legacy and Corporate Social Responsibility: Emerging Benefit Sharing Frameworks in the Irkutsk Oil Region, Russia. Sustainability 2018, 10, 3334. [CrossRef]

3. Petrov, A.N.; Tysiachniouk, M. Benefit Sharing in the Arctic: A Systematic View. Resources 2019, 8, 155. [CrossRef]

4. Brayboy, B.M.J. Toward a Tribal Critical Race Theory in Education. Urban Rev. 2005, 37, 425-446. [CrossRef]

5. Brayboy, B.M.J. Tribal Critical Race Theory: An Origin Story and Future Directions. In Handbook of Critical Race Theory in Education; Lynn, M., Dixson, A.D., Eds.; Routledge: New York, NY, USA, 2013; pp. 88-100.

6. Horowitz, L.S. Indigenous rights and the persistence of industrial capitalism: Capturing the law-ideology-power triple-helix. Prog. Hum. Geogr. In Press.

7. Bell, D.A. Brown v. Board of Education and the Interest-Convergence Dilemma. Harv. Law Rev. 1980, 93, 518-533. [CrossRef]

8. Kvale, S. Doing Interviews; SAGE: Thousand Oaks, CA, USA, 2008.

9. Morgera, E. Fair and equitable benefit-sharing at the cross-roads of the human right to science and international biodiversity law. Laws 2015, 4, 803-831. [CrossRef]

10. Rosendal, G.K. Balancing access and benefit sharing and legal protection of innovations from bioprospecting: Impacts on conservation of biodiversity. J. Environ. Dev. 2006, 15, 428-447. [CrossRef]

11. Tysiachniouk, M.S. Disentangling Benefit-Sharing Complexities of Oil Extraction on the North Slope of Alaska. Sustainability 2020, 12, 5432. [CrossRef]

12. Tysiachniouk, M. Benefit-sharing arrangements in the Arctic: Promoting sustainability of Indigenous communities in Areas of Resource Extraction. Arct. Int. Relat. 2016, 4, 18-21. 
13. Tysiachniouk, M.S.; Petrov, A.N. Benefit sharing in the Arctic energy sector: Perspectives on corporate policies and practices in Northern Russia and Alaska. Energy Res. Soc. Sci. 2018, 39, 29-34. [CrossRef]

14. Tysiachniouk, M.; Henry, L.A.; Lamers, M.; van Tatenhove, J.P. Oil Extraction and Benefit Sharing in an Illiberal Context: The Nenets and Komi-Izhemtsi Indigenous Peoples in the Russian Arctic. Soc. Nat. Resour. 2018, 31, 556-579. [CrossRef]

15. Tysiachniouk, M.; Olimpieva, I. Caught between Traditional Ways of Life and Economic Development: Interactions between Indigenous Peoples and an Oil Company in Numto Nature Park. Arct. Rev. 2019, 10, 56-78. [CrossRef]

16. Albiston, C.R.; Leachman, G.M. Law as an Instrument of Social Change. In International Encyclopedia of the Social \& Behavioral Sciences, 2nd ed.; Wright, J.D., Ed.; Elsevier: Amsterdam, The Netherlands, 2015; pp. 542-549.

17. Rosenberg, G.N. The Hollow Hope: Can Courts Bring About Social Change? 2nd ed.; University of Chicago Press: Chicago, IL, USA, 2008.

18. Brodsky, B.; Persikov, A.V. Molecular Structure of the Collagen Triple Helix. In Advances in Protein Chemistry; Parry, D.A.D., Squire, J.M., Eds.; Fibrous Proteins: Coiled-Coils, Collagen and Elastomers; Academic Press: Cambridge, MA, USA, 2005; pp. 301-339.

19. Horowitz, L.S. 'It shocks me, the place of women': Intersectionality and mining companies' retrogradation of Indigenous women in New Caledonia. Gend. Place Cult. 2017, 24, 1419-1440. [CrossRef]

20. Delgado, R. A comment on Rosenberg's new edition of The Hollow Hope. Northwest. Univ. Law Rev. 2008, 103, 147-152.

21. Yandle, B. Bootleggers and Baptists in the Theory of Regulation. In Handbook on the Politics of Regulations; Levi-Faur, D., Ed.; Edward Elgar: Cheltenham, UK, 2011; pp. 25-33.

22. Thornton, D.; Kagan, R.A.; Gunningham, N. When Social Norms and Pressures are not Enough: Environmental Performance in the Trucking Industry. Law Soc. Rev. 2009, 43, 405-436. [CrossRef]

23. Pavel, C.E.; Lefkowitz, D. Skeptical challenges to international law. Philos. Compass 2018, 13, 12511. [CrossRef]

24. Engle, K. The Elusive Promise of Indigenous Development: Rights, Culture, Strategy; Duke University Press: Durham, UK, 2010.

25. Berkowitz, L.; Walker, N. Laws and Moral Judgments. Sociometry 1967, 30, 410-422. [CrossRef]

26. Marshall, A.M. Injustice Frames, Legality, and the Everyday Construction of Sexual Harassment. Law Soc. Inq. 2003, 28, 659-689. [CrossRef]

27. Darmer, M.K.B. The enduring force of Scalia's Lawrence and Romer dissents: The case for Proposition 8. Berkeley La Raza Law J. 2012, 22, 155-174.

28. Simmons, B.A. From Ratification to Compliance: Quantitative Evidence on the Spiral Model. In The Persistent Power of Human Rights: From Commitment to Compliance; Risse, T., Ropp, S.C., Sikkink, K., Eds.; Cambridge University Press: Cambridge, UK, 2013; pp. 43-59.

29. Allen, J. Lost Geographies of Power; Blackwell: Malden, MA, USA, 2003.

30. Allen, J. Topological twists: Power's shifting geographies. Dialogues Hum. Geogr. 2011, 1, 283-298. [CrossRef]

31. Horowitz, L.S. Rhizomic resistance meets arborescent assemblage: UNESCO World Heritage and the disempowerment of Indigenous activism in New Caledonia. Ann. Am. Assoc. Geogr. 2016, 106, 167-185. [CrossRef]

32. Stetson, G. Oil Politics and Indigenous Resistance in the Peruvian Amazon. J. Environ. Dev. 2012, $21,76-97$. [CrossRef]

33. Horowitz, L.S. Toward Empathic Agonism: Conflicting Vulnerabilities in Urban Wetland Governance. Environ. Plan. A Econ. Space 2013, 45, 2344-2361. [CrossRef]

34. Van Dijk, T.A. Ideology: A Multidisciplinary Approach; SAGE: London, UK, 1998.

35. Zanotto, J.M. The role of discourses in enacting neoliberal urbanism: Understanding the relationship between ideology and discourse in planning. Plan. Theory 2020, 19, 104-126. [CrossRef]

36. Peet, R. Ideology, Discourse, and the Geography of Hegemony: From Socialist to Neoliberal Development in Postapartheid South Africa. Antipode 2002, 34, 54-84. [CrossRef]

37. Ferree, M.M. Resonance and Radicalism: Feminist Framing in the Abortion Debates of the United States and Germany. Am. J. Sociol. 2003, 109, 304-344. [CrossRef]

38. Nadasdy, P. Transcending the Debate over the Ecologically Noble Indian: Indigenous Peoples and Environmentalism. Ethnohistory 2005, 52, 291-331. [CrossRef] 
39. Radcliffe, S.A. Dilemmas of Difference; Indigenous Women and the Limits of Postcolonial Development Policy; Duke University Press: Durham, UK, 2015.

40. Horowitz, L.S. Indigenous by Association: Legitimation and Grassroots Engagements with Multinational Mining in New Caledonia. In Grassroots Environmental Governance: Community Engagements with Industry; Horowitz, L.S., Watts, M.J., Eds.; Routledge: London, UK, 2017; pp. 80-100.

41. Weatherdon, M.S. Indigenous Knowledge and Contested Spirituality in Canadian Nuclear Waste Management. J. Study Relig. Nat. Cult. 2017, 11, 86-108. [CrossRef]

42. Chiaravalloti, R. The Displacement of Insufficiently 'Traditional' Communities: Local Fisheries in the Pantanal. Conserv. Soc. 2019, 17, 173-183. [CrossRef]

43. Hope, J. The constraints of an 'ironic scholar': Negotiating critical engagement with indigeneity and nature conservation. Geoforum 2017, 78, 74-81. [CrossRef]

44. Li, T.M. Articulating Indigenous identity in Indonesia: Resource politics and the tribal slot. Comp. Stud. Soc. Hist. 2000, 42, 149-179.

45. Hodgson, D.L. Precarious Alliances: The Cultural Politics and Structural Predicaments of the Indigenous Rights Movement in Tanzania. Am. Anthr. 2002, 104, 1086-1097. [CrossRef]

46. Karlsson, B.G. Anthropology and the 'Indigenous Slot'. Crit. Anthr. 2003, 23, 403-423. [CrossRef]

47. Taylor, J.J. Naming the land: San countermapping in Namibia's West Caprivi. Geoforum 2008, 39, $1766-1775$. [CrossRef]

48. Radcliffe, S.A. Geography and indigeneity I: Indigeneity, coloniality and knowledge. Prog. Hum. Geogr. 2017, 41, 220-229. [CrossRef]

49. Hasteh, P. An Analysis on the Duty of the State to Protect Indigenous Peoples Affected by Transnational Corporations and Other Business Enterprises; E/C.19/2012/3; United Nations Economic and Social Council: New York, NY, USA, 2012.

50. Jung, C. The politics of Indigenous identity: Neoliberalism, cultural rights, and the Mexican Zapatistas. Soc. Res. 2003, 70, 433-462.

51. Schumann, C. Competing Meanings: Negotiating Prior Consultation in Brazil. J. Lat. Am. Caribb. Anthr. 2018, 23, 541-559. [CrossRef]

52. Novikova, N.I. Hunters and Oil Men: The Study on Judicial Anthropology; Nauka: Moscow, Russia, 2014.

53. Risse, T.; Sikkink, K. The Socialization of International Human Rights Norms Into Domestic Practices: Introduction. In The Power of Human Rights: International Norms and Domestic Change; Risse, T., Ropp, S.C., Sikkink, K., Eds.; Cambridge University Press: Cambridge, UK, 1999; pp. 1-38.

54. Schachter, J.S. Ely at the Altar: Political Process Theory Through the Lens of the Marriage Debate. Mich. Law Rev. 2011, 109, 1363-1411.

55. Eskridge, W.N., Jr. Some Effects of Identity-based Social Movements on Constitutional Law in the Twentieth Century. Mich. Law Rev. 2002, 100, 2062-2407. [CrossRef]

56. Eskridge, W.N., Jr. Lawrence's Jurisprudence of Tolerance: Judicial Review to Lower the Stakes of Identity Politics. Minn. Law Rev. 2004, 88, 1021-1102.

57. McLaughlin, J. The price of justice: Interest-convergence, cost, and the anti-death penalty movement. Northwest. Univ. Law Rev. 2014, 108, 675-710.

58. Terry, K. Note: Community dreams and nightmares: Arizona, ethnic studies, and the continued relevance of Derrick Bell's interest-convergence thesis. N. Y. Univ. Law Rev. 2013, 88, 1483-1520.

59. Stammler, F.; Forbes, B.C. Oil and gas development in Western Siberia and Timan-Pechora. Indig. Aff. 2006, 2-3, 48-57.

60. Tuisku, T. Transition Period in the Nenets Autonomous Okrug: Changing and Unchanging Life of Nenets People. In People and the Land; Pathways to Reform in Post-Soviet Siberia; Dietrich Reimer Verlag GmbH: Berlin, Germany, 2002; pp. 189-206.

61. Golovnev, A.V.; Osherenko, G. Siberian Survival: The Nenets and Their Story; Cornell University Press: Ithaca, NY, USA, 1999.

62. Interview with the representative of the state authorities of the okrug-1, Naryan-Mar. 25 January 2019.

63. Stammler, F.; Ivanova, A. Confrontation, coexistence or co-ignorance? Negotiating human-resource relations in two Russian regions. Extr. Ind. Soc. 2016, 3, 60-72. [CrossRef] 
64. Neftegaz.ru. Oil extraction in the Nenets Autonomous District Decreased by 6.5 in 2017. Available online: https://neftegaz.ru/news/dobycha/202920-dobycha-nefti-v-nenetskom-avtonomnomokruge-v-2017-g-sokratilas-na-6-5-no-v-2018-g-ozhidaetsya-rost/ (accessed on 9 January 2020).

65. Galimova, N. North Merger. RBK. Available online: https:/www.rbc.ru/newspaper/2020/05/15/ 5ebaf5729a7947990e3e5436 (accessed on 7 July 2020).

66. Stammler, F.; Peskov, V. Building a 'culture of dialogue' among stakeholders in North-West Russian oil extraction. Eur. Asia Stud. 2008, 60, 831-849. [CrossRef]

67. Sukhanovskii, A.F. NAO-2012: Numbers, Facts, Achievements; Pomoskaya Stolitsa: Naryan-Mar, Russia, 2013.

68. Interview with the oil manager, Moscow. 16 April 2015.

69. Interview with the representative of the oil company-1, Usinsk, Komi. 10 February 2015.

70. Interview with the representative of the oil company-2, Naryan-Mar. 13 June 2011.

71. Russian Federation Ministry of Regions. Order of 9 December 2009 No. 565 on Approval of the Methodology for Calculating the Amount of Losses Caused to Associations of Indigenous Peoples of the North, Siberia and the Far East of the Russian Federation as a Result of Economic Activities and Other Activities in Places of Traditional Residence and Traditional Economic Activities of Indigenous Peoples of the Russian Federation. Available online: https:/legalacts.ru/doc/prikaz-minregiona-rf-ot-09122009-n-565/ (accessed on 5 September 2020).

72. Interview with the former representative of the reindeer-herding enterprise, Naryan-Mar. 27 December 2019.

73. Interview with the director of reindeer-herding enterprise, village C. 22 December 2019.

74. Interview with the representative of reindeer-herding enterprise-2, Naryan-Mar. 24 December 2019.

75. Interview with the representative of NAO reindeer herder Union, Naryan-Mar. 11 January 2017.

76. Interview with the Director of municipality, village A. 4 June 2011.

77. Interview with the representative of reindeer-herders, Indigenous Nenets people, living in Naryan-Mar previously involved in reindeer herding -1, Naryan-Mar. 2 June 2011.

78. Murashko, O. What is the etnologicheskaia expertiza in Russia. Sibirica 2005, 5, 77-94.

79. Xanthaki, A. Indigenous rights in the Russian Federation: The case of numerically small peoples of the Russian North, Siberia, and Far East. Hum. Rights Q. 2004, 26, 74. [CrossRef]

80. Belugin, A. A guide who knows the area. World Indig. People 2015, 31, 157-161.

81. NAO. Government Law No. 275-03 on Reindeer Herding in Nenets Autonomous Okrug. 2016. Available online: http://docs.cntd.ru/document/444863839 (accessed on 11 July 2020).

82. Interview with the director of reindeer herder's enterprise, village C. 13 January 2017.

83. Interview with the representative of the Department of Indigenous People, Naryan-Mar. 12 January 2019.

84. Interview with the representative of the NAO Reindeer Herders' Union, Naryan-Mar. 25 December 2019.

Publisher's Note: MDPI stays neutral with regard to jurisdictional claims in published maps and institutional affiliations.

(C) 2020 by the authors. Licensee MDPI, Basel, Switzerland. This article is an open access article distributed under the terms and conditions of the Creative Commons Attribution (CC BY) license (http://creativecommons.org/licenses/by/4.0/). 